\title{
Measuring the Effects of Customs and Administrative Procedures on Trade: Gravity Model for South-Eastern Europe
}

\author{
Katerina Toševska-Trpčevska \\ Ss. Cyril and Methodius University in Skopje, Faculty of Economics, \\ FYR of Macedonia \\ tosevska@eccf.ukim.edu.mk
}

\section{Dragan Tevdovski}

Ss. Cyril and Methodius University in Skopje, Faculty of Economics, FYR of Macedonia and Aarhus University, CREATES, Denmark dtevdovski@creates.au.dk
CroEconSur

Vol. 16

No. 1

April 2014

pp. 109-127

Received: November 12, 2013

Accepted: February 25, 2014

Research Article

doi:10.15179/ces.16.1.4

\section{Abstract}

This paper measures the effects of certain customs and administrative procedures on trade between the countries of South-Eastern Europe in the period 20082012. Following OECD methodology, we employ the augmented gravity model. The empirical results suggest that the number of days spent at the border and costs paid in both importer and exporter countries had significant negative influence on the volume of trade in the period 2008-2012. In addition, the model underlines that sharing the same border and being part of the former Yugoslav market are important determinants of trade in the region.

Keywords: gravity model, customs and administrative procedures, SouthEastern Europe

JEL classification: F10, F14, F15 


\section{Introduction'}

In the last two decades it has become evident that trade facilitation is a field where further liberalization could be achieved. The rules and procedures of the World Trade Organization mainly refer to tariffs and other non-tariff instruments. On the other hand, it has become more apparent that nowadays actors in international trade face different types of barriers. These barriers are administrative and sometimes informal but have significant influence on the trade of goods on the international scene. The administrative barriers mainly comprise complicated customs procedures and complex documentation requirements and have increasing influence on the international flow of goods.

A research conducted by the United Nations (2003) showed that on average in the region of the 21 member economies of the Asia-Pacific Economic Partnership in one trade transaction 27 to 30 actors were involved, 40 documents were prepared, 200 items of data were entered, of which at least 30 were entered 30 times and 60-70 percent were entered at least twice. The losses that companies suffer through delays at borders, lack of transparency and predictability, complicated documentation requirements and other outdated customs procedures are estimated to exceed in many cases the costs of tariffs (Engman, 2010). Reducing and lowering the above mentioned barriers should allow further liberalization of international trade.

Numerous trade research studies acknowledge the importance of trade facilitation measures. ${ }^{2}$ Some of them indicate the benefits of trade facilitation, some measure the effects of undertaking trade facilitation measures on trade, and others measure their impact on world income. The relative inconsistency regarding the composition of trade facilitation measures indicates that one can only roughly compare the results of the studies or underlie conclusions for all countries and

1 We would like to thank the two anonymous reviewers and also the participants of the 9th International ASECU Conference organized by the Faculty of Economics, Ss. Cyril and Methodius University in Skopje, May 30-31, 2013, Skopje, FYR of Macedonia, for their comments that have led to improvements in the paper.

2 For example, OECD Trade Policy Studies (2010), Wilson, Luo and Broadman (2003), Wilson, Mann and Otsuki (2005), Hummels and Schaur (2012) and Djankov, Freund and Pham (2006). 
regions. The only clear conclusion is that undertaking trade facilitation measures is a win-win situation for every country.

For the purposes of the analysis made in this paper we decided to take a closer look at some administrative and customs procedures. Customs and administrative procedures can be identified as necessary procedures for goods to cross borders. On the other hand, when administrative requirements go beyond what is necessary according to national policy objectives, those requirements become considerable trade barriers. In economic literature the effects of customs and administrative procedures are described as measures that "thicken" borders between countries (Wilson, 2010: 52-53). Consequently, reducing the "thickness" of borders should increase trade flows between countries.

The goal of this paper is to measure the effect of costs, time and documents on exports between a selected group of countries from South-Eastern Europe in the most recent period (2008-2012). The analysis is based on the gravity model which is used by OECD. Wilson (2010) used the gravity model to compare customs and administrative procedures between world regions in order to show that developing countries have relatively thicker borders than the developed ones. These results were then used in simulations to indicate to what extent customs and administrative procedures need to be changed to increase trade flows.

In this paper we analyze a selected group of countries from the region of SouthEastern Europe (SEE). We included five countries which are currently members of the CEFTA-2006 agreement: Albania, Bosnia and Herzegovina, Macedonia, Montenegro and Serbia. ${ }^{3}$ Moldova is excluded although it is a CEFTA-2006 member since it shares only a small portion of trade with the above mentioned countries. As a part of the geographical region of South-Eastern Europe we included Bulgaria, Croatia, Romania and Greece although they are EU members and by some indicators are much better off than the other countries in the group. Namely, the geographical closeness and border-sharing can be enhancing factors

3 Only Kosovo is not included due to non-existing data in the UN Comtrade Database. 
for increasing mutual trade. Within this context we wanted to analyze the impact of time used for certain customs and administrative procedures on trade.

The paper is organized as follows. The next section presents the existing literature on gravity models with particular emphasis on the selected group of countries from the SEE region. In Section 3 we explain the empirical model and its six specifications used for the analysis, as well as the input data. Section 4 discusses the empirical results of the different specifications of the gravity model. In the last section we highlight the main conclusions from the results in order to give future prospects for trade policy directions for these countries.

\section{Literature Review}

Starting with Linder (1961), Tinbergen (1962) and Linnemann (1966), gravity models have been extensively used in international trade literature. The basic form of gravity models describes bilateral trade as directly related to the economic size of the two countries involved and inversely related to the transportation between them, as measured by the distance between their economic centers. Augmenting the basic relationships led to further insights on the effect of other factors on international trade. With regard to the other factors, four variables are commonly added (Cheng and Wall, 2005): common language, common border, accession to free trade arrangement and common territory in the past (such as the countries of former Yugoslavia or the former Soviet Union).

Gravity models are the workhorse for applied international trade researchers because of their simplicity and high explanatory power. Leamer and Levinsohn (1995) argue that the gravity model has produced some of the clearest and most robust empirical findings in economics. However, its use does not come without potential problems. The main one is defining the specifications that will be estimated. Traditionally, gravity models have been largely based on intuitive ideas as to which variables affect trade. More recently, however, a number of "theoretical" gravity models have been developed, which use various 
micro-founded theories of international trade to develop gravity-like models (Shepard, 2012). They are based on technological differences (Ricardian model), factor endowments (Heckscher-Ohlin model), emphasize the importance of monopolistic competition and increasing returns to scale (Helpman and Krugman model) or capture the multilateral resistance relationships (Anderson and van Wincoop model).

An overview of the development of gravity models is provided in Frankel (1997), Cheng and Wall (2005) and De Benedictis and Taglioni (2011), while recent important studies applying the gravity model include Feenstra et al. (2001), Limão and Venables (2001), Clark, Dollar and Micco (2004), Nordås and Piermartini (2004), de Groot at al. (2004) and Wilson (2010). Also, the literature confirms frequent application of these models in the Central and Eastern Europe (CEE) region, where the most influential studies include Hamilton and Winters (1992), Baldwin (1994), Havrylyshyn and Al-Atrash (1998), Kaminski, Wang and Winters (1996), Jakab, Kovács and Oszlay (2001), Egger and Pfaffermayr (2003), Fidrmuc and Fidrmuc (2003) and Bussiere, Fidrmuc and Schnatz (2005).

The literature on the implementation of gravity models in the SEE region is rather scarce. Christie (2002; 2004) suggests significant differences between actual and potential trade, both within the SEE region and between the SEE region and developed countries, mainly due to the lack of transport infrastructure. Damijan, de Sousa and Lamotte (2006) analyze the trade liberalization in the SEE countries and estimate the impact of tariff and non-tariff barriers on exports of manufactured goods. They find that non-tariff barriers exhibit larger effects on trade and also conclude that preferential trade agreements between SEE countries will have a limited impact on their mutual trade since their trade potential has already been reached. Bjelić, Dragutinović Mitrović and Popović Petrović (2013) focus on one part of the SEE region, i.e., Western Balkans countries (countries in the SEE region that are still not EU members) and explore the effects of nontariff measures on intraregional trade, as well as on their exports to the EU as 
their main export market. Their analysis indicates that technical barriers to trade significantly reduce Western Balkans trade with the EU.

\section{The Empirical Model and Data}

In the first part of this section, we present the empirical model. The second part describes the data used in the model.

\subsection{The Empirical Model}

We start with the augmented gravity model of nine selected countries from South-Eastern Europe and trade flows among them in the period 2008-2012 (360 balanced panel observations).

We use the following specifications of the gravity model:

$$
\begin{aligned}
\ln E X P_{i j t} & =\beta_{0}+\beta_{1} \ln \operatorname{DOCimp}_{j t}+\beta_{2} \ln \operatorname{GDPexp}_{i t}+\beta_{3} \ln \operatorname{GDPimp}_{j t}+ \\
& +\beta_{4} \ln \operatorname{Dis}_{i j}+\beta_{5} \operatorname{LANG}_{i j}+\beta_{6} \text { BORD }_{i j}+\beta_{7} Y U M_{i j}+\mu_{i j}+\lambda_{t}+\varepsilon_{i j t}
\end{aligned}
$$

$\ln \operatorname{EXP}_{i j t}=\beta_{0}+\beta_{1} \ln$ TIMEimp $_{j t}+\beta_{2} \ln$ GDPexp $_{i t}+\beta_{3} \ln$ GDPimp $_{j t}+$

$$
+\beta_{4} \ln D i s_{i j}+\beta_{5} L A N G_{i j}+\beta_{6} B O R D_{i j}+\beta_{7} Y U M_{i j}+\mu_{i j}+\lambda_{t}+\varepsilon_{i j t}
$$

$\ln E X P_{i j t}=\beta_{0}+\beta_{1} \ln \operatorname{COSTimp~}_{j t}+\beta_{2} \ln$ GDPexp $_{i t}+\beta_{3} \ln$ GDPimp $_{j t}+$

$$
+\beta_{4} \ln D i s_{i j}+\beta_{5} L A N G_{i j}+\beta_{6} B O R D_{i j}+\beta_{7} Y U M_{i j}+\mu_{i j}+\lambda_{t}+\varepsilon_{i j t} .
$$

The variables in these three specifications are as follows: $E X P_{i j t}$ is the exports from country $i$ to country $j$ expressed in millions of US dollars, GDPexp $p_{i t}$ is the gross domestic product of the exporter country expressed in millions of US dollars, GDPimp ${ }_{j t}$ is the gross domestic product of the importer country expressed in millions of US dollars, $D i s_{i j}$ is the geographical distance between 
the main economic centers of countries $i$ and $j, L A N G_{i j}, B O R D_{i j}$ and $Y U M_{i j}$

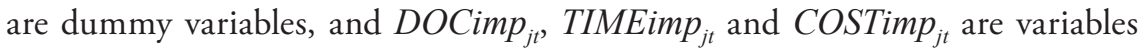
referring to customs and administrative procedures.

The variable $L A N G_{i j}$ is a dummy variable equal to 1 for countries that share a common language and 0 otherwise, $B O R D_{i j}$ is a dummy variable equal to 1 for countries that share a common border and 0 otherwise, and $Y U M_{i j}$ is a dummy variable equal to 1 for countries that were part of the ex-Yugoslav market and 0 otherwise.

The variable DOCimp $_{j t}$ refers to the number of documents of the importer country, the variable TIMEimp $j$ to the number of days at the border of the importer country, and the variable $\operatorname{COSTimp}_{j t}$ refers to costs per container of the importer country. These variables are explained in more detail in the second part of this section.

Specifications 1-3 of the gravity model are based on the recent study by Wilson (2010), which focuses on Sub-Saharan Africa and OECD countries. Wilson argues that three specifications of the model are needed because of the high correlation among the variables (DOCimp, TIMEimp and COSTimp). This is the reason why we estimate separate equations for each of these variables. Additionally, Wilson (2010) includes a dummy variable for the countries that share the same colonial history, while we include a dummy variable which represents the shared Yugoslav market in the past $(Y U M)$.

Following Wilson (2010), we use three additional specifications of the gravity model:

$$
\begin{aligned}
\ln E X P_{i j t} & =\beta_{0}+\beta_{1} \ln \left(\operatorname{DOCexp}_{j t} \cdot \operatorname{DOCimp}_{i t}\right)+\beta_{2} \ln G D P \exp _{i t}+ \\
& +\beta_{3} \ln \operatorname{GDPimp}_{j t}+\beta_{4} \ln \operatorname{DisW}_{i j}+\beta_{5} L A N G_{i j}+\beta_{6} \text { BORD }_{i j}+ \\
& +\beta_{7} Y U M_{i j}+\mu_{i j}+\lambda_{t}+\varepsilon_{i j t}
\end{aligned}
$$




$$
\begin{aligned}
\ln \operatorname{EXP}_{i j t} & =\beta_{0}+\beta_{1} \ln \left(\text { TIMEexp }_{j t} \cdot \operatorname{IMEimp}_{i t}\right)+\beta_{2} \ln \operatorname{GDPexp}_{i t}+ \\
& +\beta_{3} \ln \operatorname{GDPimp} \operatorname{PDt}_{j t}+\beta_{4} \ln \operatorname{DisW}_{i j}+\beta_{5} L A N G_{i j}+\beta_{6} \text { BORD }_{i j}+ \\
& +\beta_{7} Y U M_{i j}+\mu_{i j}+\lambda_{t}+\varepsilon_{i j t}
\end{aligned}
$$

$\ln \operatorname{EXP}_{i j t}=\beta_{0}+\beta_{1} \ln \left(\operatorname{COSTexp}_{j t} \cdot \operatorname{COSTimp}_{i t}\right)+\beta_{2} \ln \operatorname{GDP}_{\exp }+$

$$
\begin{aligned}
& +\beta_{3} \ln \text { GDPimp }_{j t}+\beta_{4} \ln \operatorname{Dis}_{i j}+\beta_{5} L A N G_{i j}+\beta_{6} \text { BORD }_{i j}+ \\
& +\beta_{7} Y U M_{i j}+\mu_{i j}+\lambda_{t}+\varepsilon_{i j t} .
\end{aligned}
$$

These three specifications use different measures of customs and administrative procedures. They use the natural logarithm of product of the corresponding variables for the importer and exporter (number of documents, days at border and costs per container). These new versions make it possible to see jointly how changes in the choice of variables affect exporters and importers. In addition, there is a different measure for the distance between two countries, a weighted distance variable $D_{i s} W_{i j}$, where geographical distance is weighted by the time at the border and remoteness. The weighted distance variable is defined as follows:

$$
\operatorname{Dis}_{i j}=\operatorname{Dis}_{i j} * \ln \left(\text { TIMEexp }_{j t} \cdot \operatorname{TIMEimp}_{i t}\right) * \operatorname{Rem}_{i t} \text {. }
$$

The purpose of the time at the border variable is straightforward because it may have a substantial effect on trade costs. The usage of the remoteness variable helps to reduce bias in the estimation as explained by Anderson and van Wincoop (2005). The formula for remoteness is based on Head (2000):

$$
\operatorname{Rem}_{i t}=\frac{1}{\frac{D i s_{i, j_{1}}}{G D P_{j t_{1}}}+\frac{D i s_{i, j_{2}}}{G D P_{j t_{2}}}+\cdots+\frac{D i s_{i, j_{r}}}{G D P_{j t_{r}}}} .
$$

The idea of using remoteness is to make an approximation for each country's set of alternatives considering the distance and economic size of the other countries. 


\subsection{The Data}

The analysis is based on annual data. The source for exports data is the UN Comtrade Database, except for data on Macedonia in 2008, where the source is International Trade Statistics of the National Bank of Macedonia. Data on GDP are from the World Bank Database. Data on geographical distance between the economic centers of two countries are from the website http://www.worldatlas. com. Data on variables relating to various customs and administrative costs come from the section "Trading across Borders" in the World Bank and International Finance Corporation survey Doing Business 2013: Smarter Regulations for Small and Medium-Size Enterprises.

In this part of the section we focus on the variables relating to customs and administrative procedures. For the analysis we use variables on documentation, time and cost. The time and cost necessary to complete every official procedure for exporting and importing are recorded, excluding the time and cost for sea transport (World Bank and International Finance Corporation, 2013: 86).

The number of documents variable measures the number of documents needed to perform one shipment or one official export or import transaction. This notion covers bank documents, customs clearance documents, port and terminal handling documents and transport documents. The documents taken into account are those that are needed per each trade transaction and not those that can be valid for a longer period of time.

The second variable relates to the time needed for exporting and importing expressed in the number of calendar days. The time calculation for one shipment starts from the moment it is initiated and runs until it is completed. The measure does not include the time for sea transport, but incorporates the time for obtaining, filling out and submitting all the documents, time for inland transport and handling, time for customs clearance and inspections and time for port operations and terminal handling (World Bank and International Finance Corporation, 2013: 124). 
It should be noted that "Trading across Borders" reports these variables expressed as averages over all exporters. In this way, Wilson (2010) argues that they serve, at best, as proxies for actual values.

The average values of the variables for the SEE countries in the period 2008-2012 are presented in Table 1.

Table 1: Trading across Borders, Averages for SEE Countries, 2008-2012

\begin{tabular}{l|c|c|c|c|c|c}
\hline Country & $\begin{array}{c}\text { Number of } \\
\text { documents } \\
\text { - export }\end{array}$ & $\begin{array}{c}\text { Days at the } \\
\text { border }- \\
\text { export }\end{array}$ & $\begin{array}{c}\text { Costs per } \\
\text { container }- \\
\text { export }\end{array}$ & $\begin{array}{c}\text { Number of } \\
\text { documents } \\
\text { - import }\end{array}$ & $\begin{array}{c}\text { Days at the } \\
\text { border }- \\
\text { import }\end{array}$ & $\begin{array}{c}\text { Costs per } \\
\text { container }- \\
\text { import }\end{array}$ \\
\hline Albania & 7 & 19.4 & 742 & 8 & 18.8 & 731 \\
\hline Bosnia & 8 & 16.6 & 1203 & 8 & 13.0 & 1145 \\
\hline Bulgaria & 4 & 21.2 & 1541 & 5 & 17.6 & 1600 \\
\hline Croatia & 7 & 20.0 & 1289 & 7 & 16.0 & 1157 \\
\hline Greece & 4 & 19.8 & 1070 & 6 & 18.2 & 1239 \\
\hline Macedonia & 6 & 12.6 & 1376 & 8 & 11.4 & 1377 \\
\hline Montenegro & 6 & 14.0 & 948 & 5.4 & 14.0 & 991 \\
\hline Romania & 5 & 13.0 & 1359 & 6 & 13.0 & 1303 \\
\hline Serbia & 6 & 13.0 & 1416 & 7 & 16.0 & 1682 \\
\hline
\end{tabular}

Source: Authors' calculations based on World Bank and International Finance Corporation (2013).

\section{Empirical Results}

The panel data gravity model is used to estimate the impact of customs and administrative procedures on trade in the selected group of countries in the SEE region. The estimates are made in Stata based on GLS random effects. We employ the random effect panel model because it allows us to include the time invariant variables in the analysis such as distance, common language, shared language and participation in the ex-Yugoslav market.

Table 2 presents the results of specifications 1 to 3 of the gravity model. As expected, there is positive impact of GDP of exporter country and GDP of importer country on the SEE countries' bilateral exports. On the other hand, the distance between countries has the expected sign but does not seem to be significant. The significant positive impacts of the two dummy variables, i.e., the 
common border and participation in the ex-Yugoslav market, imply that these variables are good proxies for the SEE countries' trade opportunities. The effect of the common language is not important. ${ }^{4}$

Table 2: Empirical Results of Gravity Model Specifications 1-3

\begin{tabular}{|c|c|c|c|}
\hline \multirow{2}{*}{$\begin{array}{l}\text { Independent } \\
\text { variable }\end{array}$} & \multicolumn{3}{|c|}{ Dependent variable ( $\ln$ Exp $_{i j t}$ in all three specifications) } \\
\hline & Model (1) & Model (2) & Model (3) \\
\hline $\ln D_{O C i m p} p_{j t}$ & $\begin{array}{r}-0.1347 \\
(0.799)\end{array}$ & & \\
\hline ln TIMEimp $_{j t}$ & & $\begin{array}{l}-0.1513 \\
(0.707)\end{array}$ & \\
\hline $\ln$ COSTimp $_{j t}$ & & & $\begin{array}{r}-0.4033 \\
(0.252)\end{array}$ \\
\hline $\ln G D P \exp _{i t}$ & $\begin{array}{r}1.0893^{* *} \\
(0.000)\end{array}$ & $\begin{array}{r}1.0892^{* *} \\
(0.000)\end{array}$ & $\begin{array}{r}1.0729^{* *} \\
(0.000)\end{array}$ \\
\hline $\ln G{ } i_{i m p} p_{j t}$ & $\begin{array}{r}0.5510^{* *} \\
(0.000)\end{array}$ & $\begin{array}{r}0.5629^{* *} \\
(0.000)\end{array}$ & $\begin{array}{l}0.5075^{* *} \\
(0.0000)\end{array}$ \\
\hline $\ln D i s_{i j}$ & $\begin{array}{r}-0.7051 \\
(0.096)\end{array}$ & $\begin{array}{r}-0.7079 \\
(0.095)\end{array}$ & $\begin{array}{r}-0.6479 \\
(0.128)\end{array}$ \\
\hline$L A N G_{i j}$ & $\begin{array}{r}0.2050 \\
(0.682)\end{array}$ & $\begin{array}{l}0.2101 \\
(0.674)\end{array}$ & $\begin{array}{l}0.2492 \\
(0.619)\end{array}$ \\
\hline$B O R D_{i j}$ & $\begin{array}{r}1.5841^{* *} \\
(0.000)\end{array}$ & $\begin{array}{r}1.5913^{* *} \\
(0.000)\end{array}$ & $\begin{array}{r}1.5938^{* *} \\
(0.000)\end{array}$ \\
\hline$Y U M_{i j}$ & $\begin{array}{r}1.3686^{* *} \\
(0.000)\end{array}$ & $\begin{array}{r}1.3460^{* *} \\
(0.000)\end{array}$ & $\begin{array}{r}1.2886^{* *} \\
(0.001)\end{array}$ \\
\hline Constant & $\begin{array}{r}-8.9147^{* *} \\
(0.000)\end{array}$ & $\begin{array}{r}-8.8606^{* *} \\
(0.000)\end{array}$ & $\begin{array}{r}-11.7576^{* *} \\
(0.000)\end{array}$ \\
\hline$R^{2}$ & 0.7174 & 0.7174 & 0.7132 \\
\hline
\end{tabular}

Notes: $p$-values are given in brackets, ${ }^{* *}$ significance at $1 \%$ level.

Regarding the customs and administrative procedures such as the number of documents of the importer country, the days at the border of the importer country and the costs per container of the importer country, we do not find any of them significant in the first three specifications of the model. These results could imply that the process of trade liberalization in the SEE region has led to loosening the observed customs and administrative procedures for export and that these

4 It should be noted that in the dummy variable we specify the existence of a common language only in a few cases. However, some pairs of countries do not have a common language, but similar languages to an extent that this does not create a significant obstacle in business contacts (for example: Croatia and Serbia, Serbia and Macedonia, Croatia and Macedonia, or Macedonia and Bulgaria). These effects are approximated by two other dummy variables: participation in the ex-Yugoslav market and common border. 
three variables are no longer important constraints to SEE trade. This result is in line with the observations by Bjelić, Dragutinović Mitrović and Popović Petrović (2013) who did not find evidence of significantly higher trade effects of the administrative barriers among the CEFTA-2006 member countries from the Western Balkans compared to the whole sample of their trading partners. However, model specifications 4 to 6 , which employ a different measure of costs and improved measure of distance, suggest that customs and administrative procedures are still important for the volume of trade in the region.

Table 3: Empirical Results of Gravity Model Specifications 4-6

\begin{tabular}{|c|c|c|c|}
\hline \multirow{2}{*}{ Independent variable } & \multicolumn{3}{|c|}{ Dependent variable $\left(\ln \operatorname{Exp}_{i j}\right.$ in all three specifications) } \\
\hline & Model (4) & Model (5) & Model (6) \\
\hline $\ln \left(D^{\prime O C \exp _{j t}} \cdot \operatorname{DOCimp}_{i t}\right)$ & $\begin{array}{r}-0.5445 \\
(0.162)\end{array}$ & & \\
\hline 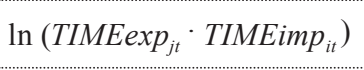 & & $\begin{array}{r}-0.0548^{*} \\
(0.854)\end{array}$ & \\
\hline $\ln \left(\operatorname{COSTexp}_{j t} \cdot \operatorname{COSTimp}_{i t}\right)$ & & & $\begin{array}{r}-1.0101^{* *} \\
(0.000)\end{array}$ \\
\hline $\ln G D P \exp _{i t}$ & $\begin{array}{r}0.8448^{* *} \\
(0.000)\end{array}$ & $\begin{array}{r}0.8774^{* *} \\
(0.000)\end{array}$ & $\begin{array}{r}0.8251^{* *} \\
(0.000)\end{array}$ \\
\hline $\ln$ GDPimp $_{j t}$ & $\begin{array}{r}0.5875^{* *} \\
(0.000)\end{array}$ & $\begin{array}{l}0.5986^{* *} \\
(0.0000)\end{array}$ & $\begin{array}{r}0.4426^{* *} \\
(0.000)\end{array}$ \\
\hline $\ln D i s W_{i j}$ & $\begin{array}{r}-0.6788^{*} \\
(0.030)\end{array}$ & $\begin{array}{r}-0.9291^{*} \\
(0.027)\end{array}$ & $\begin{array}{r}-0.4827 \\
(0.122)\end{array}$ \\
\hline$L A N G_{i j}$ & $\begin{array}{l}0.3338 \\
(0.490)\end{array}$ & $\begin{array}{l}0.2758 \\
(0.571)\end{array}$ & $\begin{array}{r}0.4542 \\
(0.336)\end{array}$ \\
\hline$B O R D_{i j}$ & $\begin{array}{r}1.5593^{* *} \\
(0.000)\end{array}$ & $\begin{array}{r}1.5829^{* *} \\
(0.000)\end{array}$ & $\begin{array}{r}1.6280^{* *} \\
(0.000)\end{array}$ \\
\hline$Y U M_{i j}$ & $\begin{array}{l}1.416^{* *} \\
(0.000)\end{array}$ & $\begin{array}{l}1.3262^{*} \\
(0.000)\end{array}$ & $\begin{array}{r}0.9940^{* *} \\
(0.005)\end{array}$ \\
\hline Constant & $\begin{array}{r}-3.0596 \\
(0.381)\end{array}$ & $\begin{array}{r}-5.3047^{*} \\
(0.096)\end{array}$ & $\begin{array}{r}-19.4429 \\
(0.000)\end{array}$ \\
\hline$R^{2}$ & 0.7294 & 0.7289 & 0.7447 \\
\hline
\end{tabular}

Notes: $p$-values are given in brackets, ${ }^{* *}$ significance at $1 \%$ level, ${ }^{*}$ significance at $5 \%$ level.

The effects of the joint changes in the variables (documents, days at border or costs) of importer and exporter countries are presented in Table 3. The costs per container and days at the border of both importer and exporter countries are significant, while the documents at the border of both importer and exporter 
countries are still not significant. The results imply that a 10 percent reduction of the costs both in importer and exporter countries may lead to an approximately 10 percent increase in export, while a 10 percent reduction of time at the border both in importer and exporter countries may lead to a 5.5 percent increase in export.

The estimated values and significance of the other variables included in model specifications 4 to 6 provide evidence for the robustness of the findings of the previous three specifications. The GDP of the exporter country and GDP of the importer country, as well as shared border and participation in ex-Yugoslav market are significant variables. In addition, the weighted distance is significant at the 5 percent level in two of the three specifications, which confirms the findings of Anderson and van Wincoop (2005). The effect of common language is not significant for bilateral export.

\section{Conclusion}

The aim of this paper was to analyze the significance of certain customs and administrative procedures and their influence on trade between the selected countries in South-Eastern Europe. The model specifications have shown that days at the border and costs paid in both importer and exporter country have significant negative influence on trade, while it seems that the number of documents needed to import or export did not have any significant influence on trade in the period 2008-2012.

The results have shown another interesting point. Sharing the same border and being part of the former Yugoslav market have shown to be statistically significant for the trade between these countries. This implies that the countries that share a common border and have shared a common history still have strong economic and trade relations. These facts should not be overlooked by the individual countries when preparing and undertaking trade facilitation measures. 
The results obtained from the analysis should be taken into consideration by the individual countries when preparing future trade policy directions. This means that the countries from South-Eastern Europe should place more attention on undertaking measures and policies that can reduce border crossing time or at least measures that will not represent an unnecessary burden to trade. One way to reduce the time needed for trade between these countries is by simplifying and harmonizing certain customs and administrative procedures. Simplification and harmonization of procedures and documents in trade have been proved in international practice as measures that facilitate trade and can be a positive impulse to promote export and trade growth.

Another aspect that arises from this analysis is the direction that can be used for setting future CEFTA-2006 prospects. All transition periods for trade liberalization and tariff reduction between CEFTA-2006 members have elapsed and future trade benefits can only be obtained by undertaking trade facilitation measures and reducing customs and administrative procedures. Since most of these countries are small, import dependent and landlocked, undertaking trade facilitation measures, especially by reducing certain customs and administrative procedures, can be the most feasible way to promote export and mutual trade.

The paper does not say anything about how to reduce the time spent at the import borders. It does not say anything about what type of reform is needed or the amount of costs for such reduction. These types of answers are possible by undertaking deeper analysis of the measures affecting trade between these countries.

The results from this paper can only be considered as indicators for the direction and relative importance of different customs and administrative procedures on trade. They, nevertheless, indicate that improving the efficiency of such customs and administrative procedures can facilitate trade and help promote export growth. 


\section{Literature}

Anderson, James and Eric van Wincoop, 2005, "Trade Costs", Journal of Economic Literature, 42, pp. 691-751. http://dx.doi.org/10.1257/0022051042177649

Baldwin, Richard E., 1994, Towards an Integrated Europe, London: Centre for Economic Policy Research.

Bjelić, Predrag, Radmila Dragutinović Mitrović and Ivana Popović Petrović, 2013, "Administrative Barriers to Trade as Predominant Non-Tariff Barriers in the Western Balkans Trade", paper presented at the 3rd International Conference on International Trade and Investment "Non-Tariff Measures: The New Frontier of Trade Policy" organized by the University of Mauritius and WTO Chairs Programme, Mauritius, September 4-6.

Bussiere, Matthieu, Jarko Fidrmuc and Bernd Schnatz, 2005, "Trade Integration of Central and Eastern European Countries: Lessons from Gravity Model”, European Central Bank Working Paper Series, No. 545, November, Frankfurt: European Central Bank.

Cheng, I-Hui and Howard J. Wall, 2005, "Controlling for Heterogeneity in Gravity Models of Trade and Integration”, Federal Reserve Bank of St. Louis Review, 87(1), pp. 49-63.

Christie, Edward, 2002, "Potential Trade in Southeast Europe: a Gravity Model Approach”, wiiw Working Papers, No. 21, March, Vienna: The Vienna Institute for International Economic Studies.

Christie, Edward, 2004, "Trade Flows in Southeast Europe", The wiiw Balkan Observatory Working Papers, No. 59, December, Vienna: The Vienna Institute for International Economic Studies.

Clark, Ximena, David Dollar and Alejandro Micco, 2004, "Port Efficiency, Maritime Transport Costs, and Bilateral Trade", Journal of Development Economics, 75(2), pp. 417-450. http://dx.doi.org/10.1016/j.jdeveco.2004.06.005 
Damijan, Jože P., José de Sousa and Olivier Lamotte, 2006, “The Effect of Trade Liberalization in South-Eastern European Countries", The wiiw Balkan Observatory Working Papers, No. 70, August, Vienna: The Vienna Institute for International Economic Studies.

De Benedictis, Luca and Daria Taglioni, 2011, "The Gravity Model in International Trade" in Luca De Benedictis and Luca Salvatici, eds., The Trade Impact of European Union Preferential Policies: An Analysis Through Gravity Models, pp. 55-90, Berlin: Springer-Verlag. http://dx.doi.org/10.1007/978-3642-16564-1_4

De Groot, Henri L.F., Gert-Jan Linders, Piet Rietveld and Uma Subramanian, 2004, "The Institutional Determinants of Bilateral Trade Patterns", Kyklos International Review for Social Sciences, 57(1), pp.103-123. http://dx.doi.org/ 10.1111/j.0023-5962.2004.00245.x

Djankov, Simeon, Caroline Freund and Cong S. Pham, 2006, "Trading on Time", World Bank Policy Research Working Paper, No. 3909, May, Washington, DC: The World Bank.

Egger, Peter and Michael Pfaffermayr, 2003, "The Proper Panel Econometric Specification of the Gravity Equation: A Three-way Model with Bilateral Interaction Effects" Empirical Economics, 28(3), pp. 571-580. http://dx.doi. org/10.1007/s001810200146

Engman, Michael, 2010, "The Economic Impact of Trade Facilitation" in OECD Trade Policy Studies, Overcoming Border Bottlenecks: The Costs and Benefits of Trade Facilitation, pp. 81-112, Paris: OECD Publishing.

Feenstra, Robert C., James R. Markusen and Andrew K. Rose, 2001, "Using the Gravity Equation to Differentiate among Alternative Theories of Trade" The Canadian Journal of Economics, 34(2), pp. 430-447. 
Fidrmuc, Jan and Jarko Fidrmuc, 2003, "Disintegration and Trade", Review of International Economics, 11(5), pp. 811-829. http://dx.doi.org/10.1046/j.14679396.2003.00419.x

Frankel, Jeffrey A., 1997, "The Gravity Model of Bilateral Trade", in Jeffrey A. Frankel, ed., Regional Trading Blocks in the World Economic System, pp. 49-76, Washington, DC: Institute of International Economics.

Hamilton, Carl B. and L. Alan Winters, 1992, "Opening up International Trade with Eastern Europe”, Economic Policy, 7(14), pp. 77-116. http://dx.doi. org/10.2307/1344513

Havrylyshyn, Oleh and Hassan Al-Atrash, 1998, "Opening Up and Geographic Diversification of Trade in Transition Economies", IMF Working Paper, No. 98/22, February, Washington, DC: International Monetary Fund.

Head, Keith, 2000, "The Gravity for Beginners", manuscript presented at "Rethinking the Line: The Canada - US Border Conference", Vancouver, October 22-25.

Hummels, David and Georg Schaur, 2012, "Time as a Trade Barrier", NBER Working Paper Series, No. 17758, January, Boston, MA: National Bureau of Economic Research.

Jakab, Zoltan M., Mihaly Kovács and Adras Oszlay, 2001, "How Far Has Trade Integration Advanced? An Analysis of the Actual and Potential Trade of Three Central and Eastern European Countries", Journal of Comparative Economics, 29(2), pp. 276-292. http://dx.doi.org/10.1006/jcec.2001.1709

Kaminski, Bartlomiej, Zhen Kun Wang and L. Alan Winters, 1996, "Export Performance in Transition Economies", Economic Policy, 11(23), pp. 421-442. http://dx.doi.org/10.2307/1344709 
Leamer, Edward E. and James Levinsohn, 1995, "International Trade Theory: the Evidence" in Gene M. Grossman and Kenneth Rogo, eds., Handbook of International Economics, Vol. 3, pp. 1339-1394, Amsterdam: Elsevier Science B.V.

Limão, Nuno and Anthony J. Venables, 2001, "Infrastructure, Geographical Disadvantage, Transport Costs, and Trade”, The World Bank Economic Review, 15(3), pp. 451-479.

Linder, Staffan, 1961, An Essay on Trade and Transformation, Uppsala: Almqvist and Wiksells.

Linnemann, Hans, 1966, An Econometric Study of International Trade Flows, Amsterdam: North-Holland.

Nordås, Hildegunn K. and Roberta Piermartini, 2004, "Infrastructure and Trade”, World Trade Organization Staff Working Paper ERSD_2004-04, Geneve: Economic Research and Statistics Division, World Trade Organization.

OECD Trade Policy Studies, 2010, Overcoming Border Bottlenecks: The Costs and Benefits of Trade Facilitation, Paris: OECD Publishing.

Shepard, Ben, 2012, The Gravity Model of International Trade: A User Guide, Geneva: UN/ESCAP.

Tinbergen, Jan, 1962, "An Analysis of World Trade Flows" in Jan Tinbergen, ed., Shaping the World Economy, New York, NY: Twentieth Century Fund.

United Nations, 2003, Income Distribution Impact of Trade Facilitation in Developing Countries, New York and Geneva: United Nations Economic Commission for Europe.

Wilson, John S., Xubei Luo and Harry Broadman, 2003, "Trade Facilitation and Economic Development: Measuring the Impact", Policy Research Working Paper 2988, Washington, DC: The World Bank. 
Wilson, John, Catherine L. Mann and Tsunehiro Otsuki, 2005, "Assessing the Benefits of Trade Facilitation: A Global Perspective", The World Economy, 28(6), pp. 841-871. http://dx.doi.org/10.1111/j.1467-9701.2005.00709.x

Wilson, Norbert, 2010, "Examining the Effect of Certain Customs and Administrative Procedures on Trade" in OECD Trade Policy Studies, Overcoming Border Bottlenecks: The Costs and Benefits of Trade Facilitation, Paris: OECD Publishing.

World Bank and International Finance Corporation, 2013, Doing Business 2013: Smarter Regulations for Small and Medium-Size Enterprises, Washington, DC: World Bank and International Finance Corporation. 